\title{
Molecular screening of tsetse flies and cattle reveal different Trypanosoma species including $T$. grayi and $T$. theileri in northern Cameroon
}

Sen Claudine Henriette Ngomtcho, 1,2,3 Judith Sophie Weber ${ }^{3}$, Elisabeth Ngo Bum', Thaddeus Terlumun Gbem ${ }^{4,5}$, Sørge Kelm ${ }^{3}$ and Mbunkah Daniel Achukwi ${ }^{6 *}$

\begin{abstract}
Background: African trypanosomes are mainly transmitted through the bite of tsetse flies (Glossina spp.). The present study investigated the occurrence of pathogenic trypanosomes in tsetse flies and cattle in tsetse fly-infested areas of Northern Cameroon.

Results: Trypanosomes were identified using nested polymerase chain reaction (PCR) analysis of internal transcribed spacer 1 (ITS1) region, both by size estimation and sequencing of PCR products. Apparent density indices recorded in Gamba and Dodeo were 3.1 and 3.6 tsetse flies per trap and day, respectively. Trypanosoma prevalence infection rate for the tsetse fly gut (40\%) and proboscis (19\%) were recorded. Among the flies where trypanosomes were detected in the gut, $41.7 \%$ were positive for T. congolense and $14.6 \%$ for T. brucei ssp., whereas in the proboscis $36 \%$ harboured T. congolense and $62 \%$ contained T. vivax. T. grayi was highly prevalent in tsetse fly gut (58\%). The most common mixed infections were the combination of T. congolense and T. grayi. Trypanosome prevalence rate in cattle blood was $6 \%$. Among these, T. vivax represented 26\%, T. congolense 35\%, T. brucei ssp. 17\% and T. theileri $17 \%$ of the infections. Surprisingly, in one case T. grayi was found in cattle. The mean packed cell volume (PCV) of cattle positive for trypanosomes was significantly lower $(24.1 \pm 5.6 \% ; P<0.05)$ than that of cattle in which trypanosomes were not detected $(27.1 \pm 4.9 \%)$. Interestingly, the occurrence of $T$. theileri or T. grayi DNA in cattle also correlated with low PCV at pathological levels.

Conclusion: This molecular epidemiological study of Trypanosoma species in Northern Cameroon revealed active foci of trypanosomes in Dodeo and Gamba. These findings are relevant in assessing the status of trypanosomosis in these regions and will serve as a guide for setting the priorities of the government in the control of the disease.
\end{abstract}

Keywords: Trypanosoma grayi, Trypanosoma theileri, Bodonidae, Cattle, Tsetse fly, ITS1, Trypanosomosis, Northern Cameroon

\footnotetext{
*Correspondence: dmbunkahachukwi@gmail.com

${ }^{6}$ TOZARD Research Laboratory, P.O. Box 59, Bambili-Tubah, Bamenda,

Cameroon

Full list of author information is available at the end of the article
} International License (http://creativecommons.org/licenses/by/4.0/), which permits unrestricted use, distribution, and reproduction in any medium, provided you give appropriate credit to the original author(s) and the source, provide a link to the Creative Commons license, and indicate if changes were made. The Creative Commons Public Domain Dedication waiver (http://creativecommons.org/publicdomain/zero/1.0/) applies to the data made available in this article, unless otherwise stated. 


\section{Background}

Trypanosomes are a group of flagellated protozoans that include Trypanosoma brucei gambiense, responsible for human African trypanosomiasis (HAT) in West and Central Africa, and Trypanosoma brucei rhodesiense in East Africa [1]. Several other species are responsible for animal African trypanosomosis (AAT), also called "nagana", mostly caused by $T$. congolense, T. vivax and $T$. brucei brucei [2]. These salivarian parasites are transmitted during the blood meal of an infected vector insect, whereas stercorarian trypanosomes, i.e. T. grayi, develop in the gut and are transmitted via faeces [3].

Usually, tsetse flies (Diptera: Glossinidae) are vectors of pathogenic trypanosomes in sub-Saharan Africa [4]. However, other biting flies like the Tabanidae and species of Stomoxys can mechanically transmit parasites [5, 6]. Thirty-three extant species and sub-species of Glossina, restricted to sub-Saharan Africa, have been reported [7]. They have been divided into three groups based on their distribution patterns and morphological features and include the savannah species (e.g. G. morsitans), the forest species (e.g. G. fusca) and the riverine species (e.g. G. palpalis). In the vector Glossina, T. congolense colonises the gut and the proboscis, whereas $T$. brucei spp. colonise the gut and the salivary glands [8]. Trypanosoma vivax occurs exclusively in the proboscis and degenerates when ingested with a blood meal to the mid-gut [9]. As transmission depends wholly on feeding, the trypanosomosis risk is usually related to tsetse fly density, trypanosome infection rates, and contact between hosts and vectors [1]. Remote rural areas are typically prone to high levels of the disease. Considered the "beef basket" region of Cameroon, several control strategies were carried out in the Adamawa region targeting bovine trypanosomosis to mitigate its devastating impact on livestock [10]. However, its recent resurgence has been favoured by factors such as climate and vegetation changes, and the interruption of control and treatment programs [11]. The stoppage of tsetse fly control activities by aerial spraying of insecticides in the Adamawa region [12] has led to an exaggerated threat from tsetse flies, which occur towards the north of the area [11]. Trypanosomosis is devastating and imposes major economic constraints on livestock farmers, least capable of affording treatment costs. To establish successful control measures, it is essential to identify the different Trypanosoma species in circulation and evaluate their distribution in vector and mammalian hosts. While some information exists about the trypanosomiasis status in South Cameroon [13-16], little data is available for the northern area of the country, especially regarding molecular epidemiology. The main information available is that areas previously free of tsetse flies have been reinvaded [11], despite the action of the Mission spéciale d'éradication des glossines (MSEG), which was established to eradicate tsetse flies. Several studies limited to parasitological and serological parameters of trypanosomosis have been undertaken in this region [12, 17-20]. DNA-based approaches for the detection of trypanosomes, such as those using polymerase chain reaction (PCR) [21-24], have greatly improved in the last decades. Taking advantage of this, we used PCR-based methods to identify different Trypanosoma species in the gut and proboscis tissue from tsetse flies as well as in blood samples from cattle in some villages in the Adamawa and the northern region of Cameroon. Obtained results will contribute to developing guidelines for trypanosomosis control measures in this area.

\section{Methods}

\section{Study sites}

This study was undertaken in Northern Cameroon, in the vicinity of Adamawa and the North Region. During the dry season between November and April the dry wind comes from the northeast, originating in the Sahara Desert. From May to October, which is the wet season, humid air is drawn from the southwest. Adamawa lies at $6^{\circ} 20^{\prime} \mathrm{N}, 13^{\circ} 30^{\prime} \mathrm{E}$ and covers an area of $63,701 \mathrm{~km}^{2}$ (Fig. 1). It is dominated by sparse tree vegetation known as Guinea savannah [10]. The survey was conducted in the Faro et Deo division (Fig. 1), which covers an area of $10,435 \mathrm{~km}^{2}$ with a total population of about 67,000 in 2005 [25]. The North Region lies at $8^{\circ} 30^{\prime} \mathrm{N}, 14^{\circ} 00^{\prime} \mathrm{E}$ and covers an area of $66,090 \mathrm{~km}^{2}$. The target division in the North Region was Mayo-Rey (Fig. 1), which covers an area of $36,529 \mathrm{~km}^{2}$ with a total population of about 375,000 in 2005 [25].

\section{Tsetse fly collection and processing}

A cross-sectional tsetse fly survey was conducted along the main rivers of both Adamawa (Mayo Deo) and the North Region (Bénoué) of Cameroon during the dry season in March 2014. In Dodeo, flies were collected at two separate sites (Fig. 1). At both sites, traps were placed along small rivers. The forest gallery vegetation along the river banks provided shadows leading to a relatively cool environment. In Gamba and Alme, the collection sites were characterised by a savannah gallery. Twelve biconical traps and four Vavoua traps were set up at each site with $100 \mathrm{~m}$ spacing and baited with acetone. To keep as many flies as possible alive in the traps, these were placed as much as possible in the shade of trees. Traps were deployed around 7:00 h and left for 2 days. The traps were inspected twice every day for fly collection at 12:00 $\mathrm{h}$ and 17:00 $\mathrm{h}$. In areas that were very remote and difficult to access, the harvest took place once per day, around 17:00 h. The number of flies per trap and time of collection were recorded. To assess the 

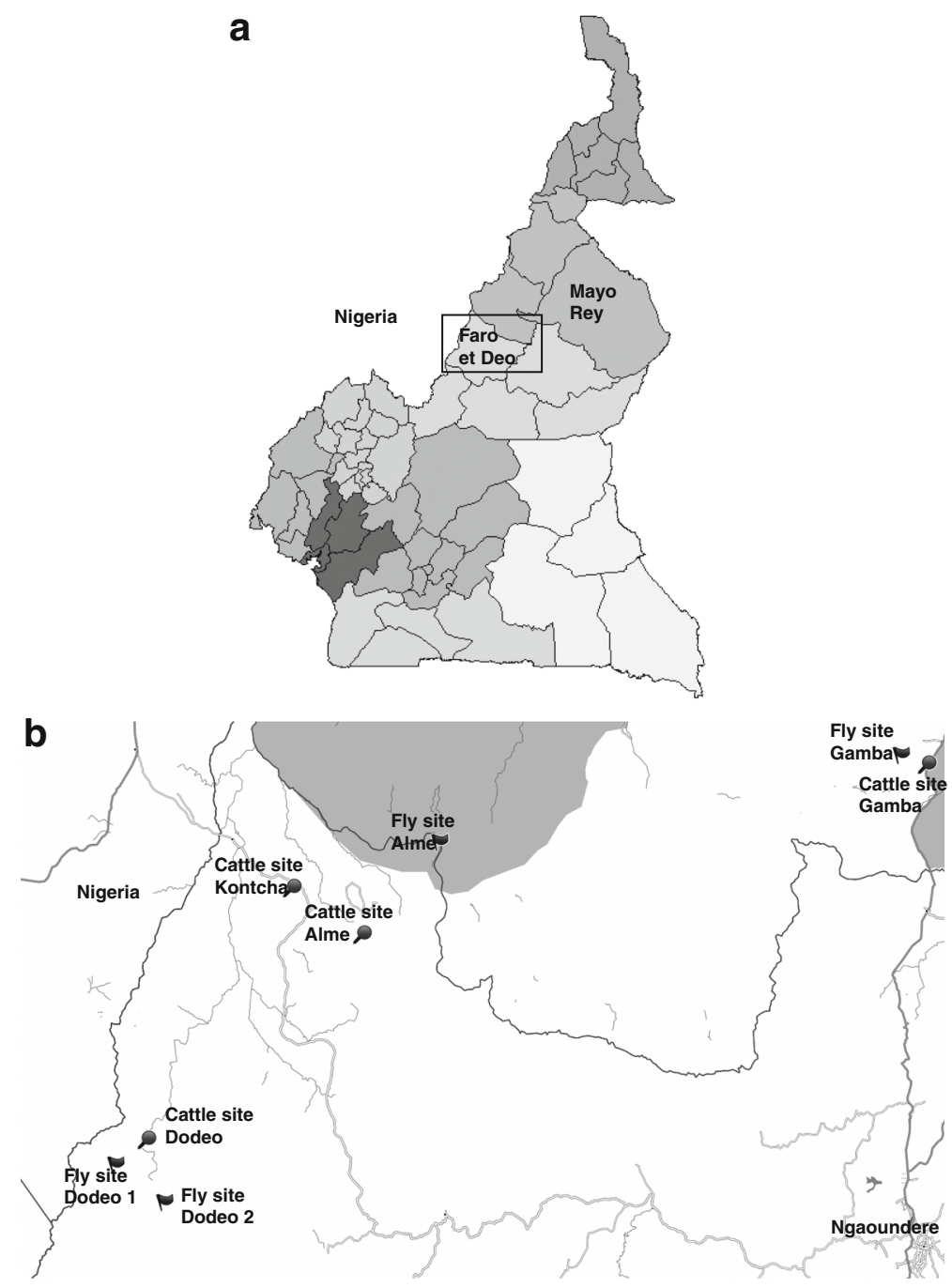

Fig. 1 Maps of the study areas. a The study area lies in the north of Cameroon, showing the administrative divisions. b Site locations: Gamba in the North Region and Dodeo, Alme and Kontcha in the Adamawa Region. Sites for flies trapping and cattle sampling are indicated. Grey shaded areas indicate the national parks Faro (near Alme) and Bénoué (near Gamba)

relative abundance of tsetse flies at each trapping site, the apparent density was estimated as the total number of tsetse flies caught per trap per day [26]. Geographical coordinates were documented using a GPS device (Garmin GPSMAP 60csx) and environmental parameters (temperature and relative humidity) recorded using a data logger (EasyLog TH, Lascar, Whiteparish, UK).

Tsetse flies were identified using morphological characteristics such as a distinct proboscis, folded wings at rest with hatchet cells, and branched arista hairs on the antennae. Males have a hypopogium and are smaller than females which have a vulva. The following key characteristics were used to identify Glossina species: the colour of the tarsal segments of the hind and front legs, and the colour and the shape of the dorsal surfaces of the abdomen with or without banding [27].
Identification of tsetse fly species was further confirmed by sequencing parts of the cytochrome $c$ oxidase 1 (cox1) [28] as described below.

Gut and proboscis tissues were dissected from each fly and placed in a $1.5 \mathrm{~mL}$ cryotube, containing $200 \mu \mathrm{L}$ of nucleic acid preservation agent (NAPA; $25 \mathrm{mM}$ sodium citrate, $10 \mathrm{mM}$ ethylenediaminetetraacetic acid (EDTA), $70 \mathrm{~g}$ ammonium sulfate $/ 100 \mathrm{ml}$ solution, $\mathrm{pH}$ 7.5). Samples were kept at $-20{ }^{\circ} \mathrm{C}$ in the field, and subsequently transferred to $-80{ }^{\circ} \mathrm{C}$ upon arrival in the laboratory. Non-teneral flies were recorded. To avoid contamination between tissues, the proboscis was removed from the flies' head before opening the abdomen. To avoid cross-contamination, we used fresh dissection pins and forceps for each fly tissue, decontaminated by incubation in 5\% sodium hypochlorite 
solution for $20 \mathrm{~min}$ and subsequently washed thoroughly with double distilled water.

\section{Blood collection from cattle, processing and PCV measurement}

Blood was collected from the jugular vein of 392 cattle directly into blood collection tubes containing EDTA (Sarstedt, Nürnbrecht, Germany). The collected blood was centrifuged at $3000 \times \mathrm{rpm}$ for $15 \mathrm{~min}$. The upper layer containing plasma and the buffy coat was collected separately in $1.5 \mathrm{~mL}$ cryotubes. NAPA was added to the buffy coat resulting in a 1:4 final dilution. The PCV of each blood sample was measured following centrifugation in heparinised haematocrit capillary tubes at $12,000 \times \mathrm{rpm}$ for $5 \mathrm{~min}$ (haematocrit centrifuge from Hawksley, UK). An animal with a PCV value below 25\% was considered to be anaemic [11].

\section{DNA extraction and quantification}

DNA was extracted from tsetse fly gut or buffy coat from cattle blood using the DNeasy Blood and Tissue Kit (Qiagen, Hilden, Germany) according to the manufacturer instructions and photometrically quantified using Nanodrop 1000 apparatus (Thermo Scientific, Dreieich, Germany) at a wavelength of $260 \mathrm{~nm}$. To obtain DNA from proboscis, they were ground using a single-use microfuge pestle (Sigma Aldrich, Munich, Germany) in a 1.5. ml microfuge and taken up in $50 \mu \mathrm{l}$ PBS. The homogenised tissue was then used for PCR without further DNA purification.

\section{Identification of Glossina species by sequencing of the cox 1 gene}

To identify tsetse fly species also on the genetic level, we amplified and sequenced part of the cox1 gene [28] using the primers listed in Table 1. PCR reactions $(25 \mu \mathrm{l})$ contained $5 \mu \mathrm{l}$ template DNA, $2 \mu \mathrm{M}$ of primers, $20 \mu \mathrm{M}$ of dNTPs (Thermo Fisher Scientific, Dreieich, Germany) and DreamTaq Green polymerase (Thermo Fisher Scientific). PCR cycling reactions included an initial denaturation $95{ }^{\circ} \mathrm{C}$ for $5 \mathrm{~min}$, followed by 35 cycles of $1 \mathrm{~min}$ at $94{ }^{\circ} \mathrm{C}, 1 \mathrm{~min}$ at $55{ }^{\circ} \mathrm{C}$, and $2 \mathrm{~min}$ at $72{ }^{\circ} \mathrm{C}$, and a final elongation of $10 \mathrm{~min}$ at $72{ }^{\circ} \mathrm{C}$. Fragments were purified on a $1.5 \%$ agarose gel containing $0.5 \mu \mathrm{g} / \mathrm{ml}$ of SERVA DNA Stain G (SERVA, Heidelberg, Germany) and sequenced as described below.

\section{Detection and identification of Trypanosoma species}

Nested PCR targeting the internal transcribed spacer 1 (ITS1) region of the trypanosome ribosomal DNA, which separates $28 \mathrm{~S}$ from 5.8S RNA, was performed. First, identification was made using size estimation of amplicons generated by use of generic primers (Table 1). For further confirmation of the species, primer sets specific for several Trypanosoma species were designed to amplify regions of trypanosomal $18 \mathrm{~S}$ ribosomal RNA (Table 1).

ITS1 nested PCR reactions for detection of trypanosomal DNA with generic primers were performed in a $25 \mu \mathrm{l}$ reaction volume containing DreamTaq Green DNA polymerase and DreamTaq Green buffer (Thermo

Table 1 Primers used in this study to amplify different Trypanosoma species

\begin{tabular}{|c|c|c|c|c|c|}
\hline Name & Sequence $\left(5^{\prime}-3^{\prime}\right)$ & $\mathrm{TA}\left({ }^{\circ} \mathrm{C}\right)$ & Amplicon size (bp) & Species & Reference \\
\hline ITS1-OutF & TGCAATTATTGGTCGCGC & 54 & Variable & All Trypanosoma species & [22] \\
\hline ITS1-OutR & CTTGCTGCGTTCTT & & & & \\
\hline ITS1-InF & TAGAGGAAGCAAAAG & & & & \\
\hline ITS1-InR & AAGCCAAGTCATCCATCG & & & & \\
\hline TCON-OutF & TGCAATTATTGGTCGCGC & 54 & 681 (kilifi) or 781 (forest) & T. congolense & [22] \\
\hline TCON-OutR & TGCAATTATTGGTCGCGC & & & & \\
\hline TCON-InF & TCGCGTGTCTCACGT & & & & \\
\hline TCON-InR & TCAAAGATTGGGCAATGT & & & & \\
\hline TGR-OutF & TGGCAGACACATACCTGCCA & 54 & 526 & T. grayi & This study \\
\hline TGR-OutR & TGGGGATTACGGATGAAAC & & & & \\
\hline TGR-InF & TTAAGGAGGCGCTCAGGTTC & & & & \\
\hline TGR-InR & TGTGCATATACGTCTATG & & & & \\
\hline TVIV-F & CTGAGTGCTCCATGTCCCAC & 60 & 142 & T. vivax & [24] \\
\hline TVIV-R & CCACCAGAACACCAACCTGA & & & & \\
\hline $\mathrm{COI}-\mathrm{F}$ & TTGATTITTTGGTCATCCAGAAGT & 55 & 900 & Generic Glossina cox 1 & [28] \\
\hline COI-R & TGAAGCTTAAATTCATTGCACTAATC & & & & \\
\hline
\end{tabular}

Abbreviations: TCON, T. congolense; TGR, T. grayi; TVIV, T. vivax; cox1, cytochrome c oxidase 1; Out, outer primer; In, inner primer; F, forward; R, reverse; TA, annealing temperature 
Scientific). The first reaction containing $1 \mathrm{ng} / \mu \mathrm{l}$ of DNA template and $2 \mu \mathrm{M}$ of primers (ITS1-OutF and ITS1OutR, Table 1) was run under the following conditions: initial denaturation at $95^{\circ} \mathrm{C}$ for $1 \mathrm{~min}, 30$ cycles of $94{ }^{\circ} \mathrm{C}$ for $1 \mathrm{~min}$, annealing at $54{ }^{\circ} \mathrm{C}$ for $30 \mathrm{~s}$, elongation at $72^{\circ}$ $\mathrm{C}$ for $30 \mathrm{~s}$, followed by a final elongation step at $72{ }^{\circ} \mathrm{C}$ for $5 \mathrm{~min}$. First PCR products were diluted 80 -fold and $1 \mu \mathrm{l}$ of this dilution was used for the second PCR reaction with ITS1-InF and ITS1-InR primers (Table 1) under the same conditions as the first reaction. As discussed by Adams et al. [24], with this nested PCR, DNA of a single parasite can be detected.

Regarding specific identification, the annealing temperature was $54{ }^{\circ} \mathrm{C}$ for the first reaction and was varied during the second reaction based on the melting temperatures of the primer sets $60{ }^{\circ} \mathrm{C}$ for $T$. vivax and $54{ }^{\circ} \mathrm{C}$ for all other Trypanosoma species. To optimise the PCR with primers specific for $T$. grayi, the $\mathrm{MgCl}_{2}$ concentration of the DreamTaq Green buffer (Thermo Scientific) was increased by adding $2 \mathrm{mM}$ $\mathrm{MgCl}_{2}$. Amplified products were resolved by electrophoresis on $1.5 \%$ or $2 \%$ agarose gels.

\section{Purification and subcloning of selected PCR products}

Selected PCR products were carefully excised from the gel using a clean scalpel. DNA was purified using GeneJet Gel Extraction Kit (Thermo Scientific), following the instructions of the manufacturer. DNA concentrations were determined at a wavelength of $260 \mathrm{~nm}$ on a Nanodrop 1000 apparatus (Thermo Scientific). Purified PCR products were cloned into either the linearized plasmid vector PCR $^{\text {ma }}$ 2.1-TOPO (Thermo Scientific) with single 3'- deoxythymidine (T) overhangs or linearised pJET 1.2/blunt plasmid using the CloneJET PCR (Thermo Scientific), according to the manufacturer's instructions. Positive clones were identified by colony PCR and selected single colonies were cultured in LB plus ampicillin $(100 \mu \mathrm{g} / \mathrm{ml})$ with shaking overnight at $37^{\circ} \mathrm{C}$. Bacteria were collected by centrifugation $\left(4500 \times g, 15 \mathrm{~min}\right.$ at $\left.4{ }^{\circ} \mathrm{C}\right)$ and the plasmid DNA was purified using the NucleoBond Xtra Midi Plus MidiPrep Kit (Macherey-Nagel, Düren, Germany), or GeneJET Plasmid MiniPrep Kit (Thermo Fischer Scientific), according to the instructions of the manufacturer.

\section{Sequencing of PCR products}

In the initial phase of the project, subcloned PCR products were sequenced employing the Big Dye Terminator v3.1 Cycle Sequencing Kit (Applied Biosystems, Dreieich, Germany) according to the manufacturer's instructions. The samples were incubated for $2 \mathrm{~min}$ at $95{ }^{\circ} \mathrm{C}$ for initial denaturation of DNA, followed by 60 sequencing reaction cycles $\left(95{ }^{\circ} \mathrm{C}\right.$ for $15 \mathrm{~s}, 58^{\circ} \mathrm{C}$ for $15 \mathrm{~s}, 60^{\circ} \mathrm{C}$ for 4 min and $60{ }^{\circ} \mathrm{C}$ for $7 \mathrm{~min}$ ) and then held at $4{ }^{\circ} \mathrm{C}$. Reactions were then purified using Sephadex 50 in 96 well plates previously equilibrated with distilled water at $4{ }^{\circ} \mathrm{C}$ and sequencing was done at the Max Planck Institute for Marine Microbiology in Bremen, using a Genetic Analyzer (Applied Biosystems).

In a later stage of the project, PCR products were sequenced directly after gel purification or following subcloning into a pJET1.2/blunt vector (Thermo Scientific) by SeqLab, Göttingen, Germany.

\section{Bioinformatics and statistical analysis}

Obtained data were evaluated using SPSS software version 22.0. Chi-square analysis was employed to compare prevalence rates. A Student's t-test (unpaired, two-tailed) was used to compare mean PCV values. Differences were tested for significance at $P<0.05$. Geneious bioinformatics software (Biomatters, Auckland, New Zealand) was used to analyse the sequencing results. For alignments of the DNA sequences the matrix of the Geneious Alignment tool was used, applying a gap open penalty of 12 , a gap extension penalty of 1.5 and the alignment type "global alignment with free end gaps". The cost matrix was set to 51-93\% alignment with free end gaps, depending on the degree of similarity. Sequences were screened against databases using nucleotide BLAST searches (Megablast) at NCBI website (http://blast.ncbi.nlm.nih.gov/Blast.cgi) or TriTrypDB (version 6.0; http://tritrypdb.org) against the whole genome database.

\section{Results \\ Glossina species in the study area}

A total of 241 tsetse flies were trapped at the two study sites over a 2-day period (Table 2). Density indices of tsetse flies were 3.1 in Gamba and 3.6 in Dodeo indicating similar tsetse fly population densities in these areas.

Table 2 The numbers and species of Glossina sampled from each study area in northern Cameroon. Glossina species were identified using morphology and by sequence analysis of the cytochrome c oxidase 1 gene

\begin{tabular}{llllll}
\hline Study sites & Glossina palpalis palpalis & Glossina morsitans submorsitans & Glossina tachinoides & Glossina sp. & 18 \\
\hline Dodeo & 109 & 0 & 0 & 0 & 0 \\
Alme & 0 & 1 & 10 & 127 \\
Gamba & 0 & 103 & 104 & 10 & 0 \\
Total & 109 & 104 & 18 & 113 \\
\hline
\end{tabular}


In Alme, only a single tsetse fly was caught. In Dodeo, G. palpalis palpalis and a Glossina sp. not identified by cox1 sequencing were collected, whereas in Gamba G. tachinoides and G. morsitans submorsitans were recorded. Overall, the main tsetse species identified were G. p. palpalis and G. m. submorsitans (Table 2, Additional file 1: Tables S1-S4).

\section{Trypanosoma species identified}

The identification of trypanosomes was performed by PCR amplification of ITS1. Initially, trypanosome species were preliminarily assigned according to the band size of the product yielded. As described in the literature [24], sizes in the range between 550 and $700 \mathrm{bp}, 400-450 \mathrm{bp}$ and 198-250 bp were considered to come from T. congolense kilifi and T. congolense forest/savannah, T. brucei ssp., and T. vivax, respectively. Also, unexpected band sizes of about 320 and 100 bp were amplified (Fig. 2b, Additional file 1: Tables S1-S3).

To further check the identification, samples were subjected to PCR with specific primers where available. Finally, representative PCR products were subcloned and sequenced for final confirmation or more detailed

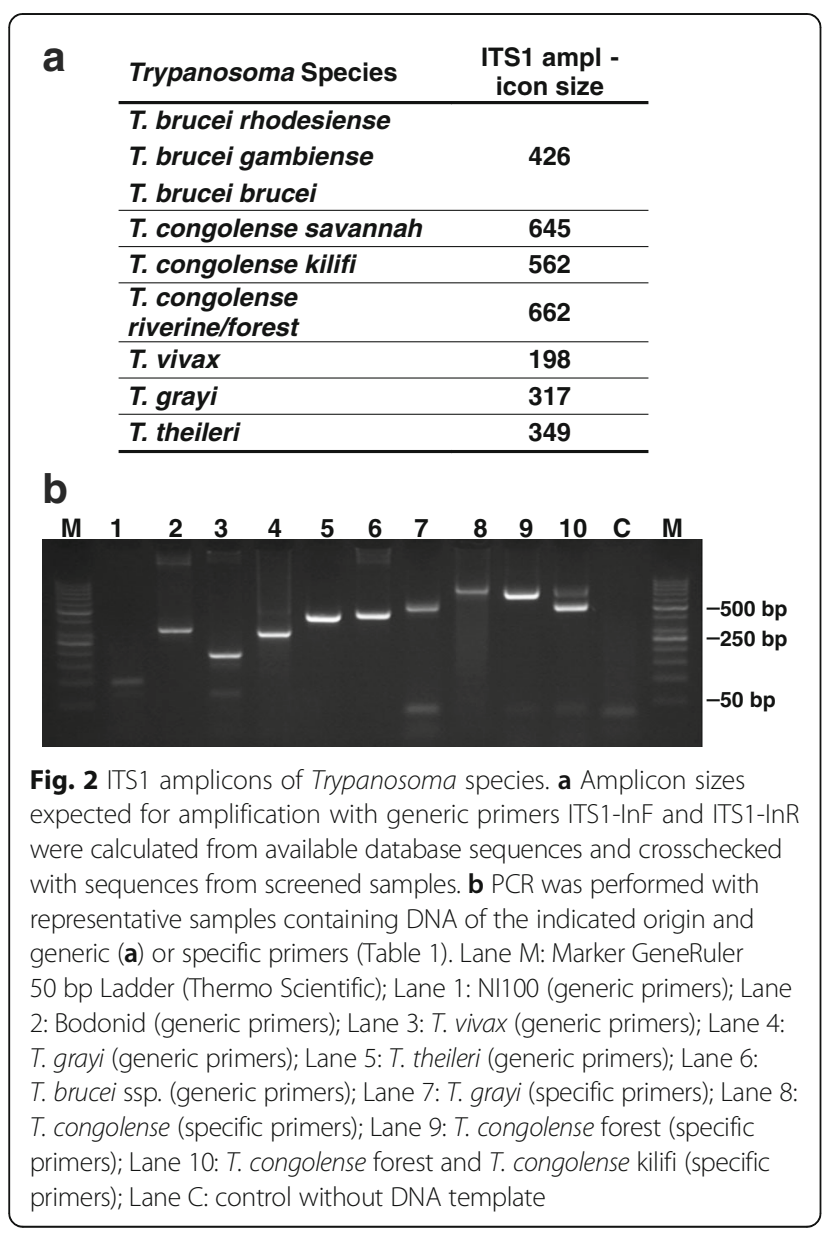

identification. The fragment sizes and respective Trypanosoma species are listed in Fig. 2 and Additional file 1: Tables S1-S4).

\section{Identification of non-assigned amplicons}

To identify the species yielding the amplicons of about $320 \mathrm{bp}$, several independent non-identified PCR products obtained from sampled tsetse tissues were purified, subcloned and sequenced. The results revealed that these amplicons represent DNA products of 310 to $317 \mathrm{bp}$, which are $91 \%$ identical to T. grayi ANR4, (Additional file 2: Figure S1). Most of the differences were small insertions or deletions in the range of 1 to $10 \mathrm{nu}-$ cleotides. To generate a tool for species identification of possible $T$. grayi candidates, specific primers annealing in the $18 \mathrm{~S}$ rRNA gene were designed based on the genomic sequence of $T$. grayi ANR4 (JMRU01000589). Primers were tested against genomic DNA from $T$. grayi ANR4 (generously provided by W. Gibson). With these primers, PCR products ranging in size between 520 and $530 \mathrm{bp}$ were amplified from corresponding tsetse fly tissues samples. Sequencing the amplicons gave 97 to $99 \%$ sequence identity to T. grayi ANR4 (Fig. 3).

Five cattle blood samples presented similar PCR products of about $320 \mathrm{bp}$ (Additional file 1: Table S3). Interestingly, in one of these cases, the sequence was also 98\% identical to T. grayi ANR4, thus revealing the presence of $T$. grayi in cattle. However, the sequences of the other four $320 \mathrm{bp} \mathrm{PCR} \mathrm{products} \mathrm{obtained} \mathrm{from} \mathrm{cattle}$ samples revealed T. theileri as the parasite (Table 3). ITS1 sequences of $T$. theileri show a relatively high degree of diversity (65-100\% sequence identity) [29, 30]. Alignment of the sequences obtained in this study indicated that the samples were derived from two distinct strains, which were also found in the database (Table 3). Within each strain, the sequences were 95-98\% identical, whereas sequence identity between these strains was only about $70 \%$.

The same approach as employed for the $320 \mathrm{bp}$ PCR products was undertaken to identify the origin of $100 \mathrm{bp}$ amplicons. However, it was observed that the sequences of subcloned PCR products were heterogeneous. Whereas several sequences looked like primer artefacts, in several samples sequence fragments were identified, which are highly conserved in the Kinetoplastidae providing a hint towards the possible kinetoplastid origin. Therefore, the $100 \mathrm{bp}$ PCR products are further referred to as NI100 (non-identified $100 \mathrm{bp}$ PCR product), and the corresponding samples were not included as Trypanosoma-positive in the calculation of prevalence rates.

\section{Trypanosoma species in tsetse fly gut}

The presence of trypanosomes in gut tissue was investigated by PCR employing primers hybridising to conserved sequences in the ITS1 regions of the Kinetoplastidae 


\begin{tabular}{|c|c|c|}
\hline MG283141 & 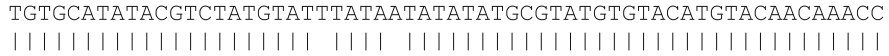 & 60 \\
\hline JMRU01000589 & TGTGCATATACGTCTATGTATATATA-TATATATGCGTATGTGTACATGTACAACAAACC & 6471 \\
\hline MG283141 & AACCAAAAACACAAAAGAGAGAGAAGCAACTTCGTAGTGTGT--GTGTGTGTGATTCGTC & 118 \\
\hline JMRU01000589 & AACCAAAAACACAAACGAGAGAGAAGAAACTTCGTAGTGTGTTTGTGTGTGTGATTCGTC & 6411 \\
\hline MG283141 & 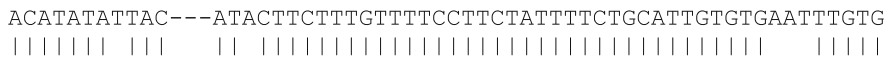 & 175 \\
\hline JMRU01000589 & ACATATACTACTACATGCTTCTTTGTTTTCCTTCTATTTTCTGCATTGTGTG---TTGTG & 6354 \\
\hline MG283141 & 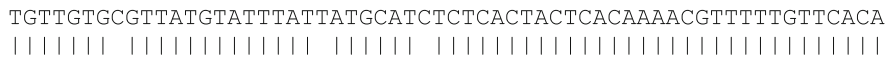 & 235 \\
\hline JMRU01000589 & TGTTGTGTGTTATGTATTTAT-ATGCATTTCTCACTACTCACAAAACGTTTTTGTTCACA & 6295 \\
\hline MG283141 & 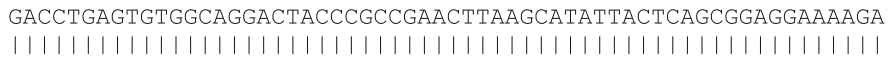 & 295 \\
\hline JMRU01000589 & GACCTGAGTGTGGCAGGACTACCCGCCGAACTTAAGCATATTACTCAGCGGAGGAAAAGA & 6235 \\
\hline MG283141 & 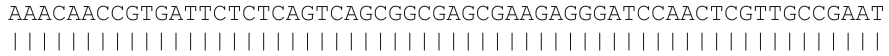 & 355 \\
\hline JMRU01000589 & AAACAACCGTGATTCTCTCAGTCAGCGGCGAGCGAAGAGGGATCCAACTCGTTGCCGAAT & 6175 \\
\hline MG28314 & 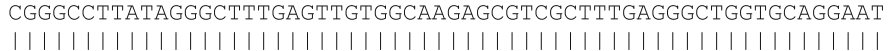 & 415 \\
\hline JMRU01000589 & CGGGCCTTATAGGGCTTTGAGTTGTGGCAAGAGCGTCGCTTTGAGGGCTGGTGCAGGAAT & 6115 \\
\hline MG28314 & 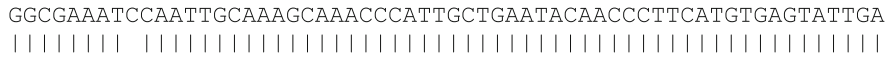 & 475 \\
\hline JMRU01000589 & GGCGAAATTCAATTGCAAAGCAAACCCATTGCTGAATACAACCCTTCATGTGAGTATTGA & 6055 \\
\hline MG2831 & 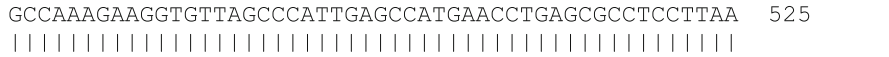 & \\
\hline JM & AAGAAGGTGTTAGCCCAT: & \\
\hline
\end{tabular}

Fig. 3 The sequence of an amplicon obtained from tsetse fly gut with primers specific for T. grayi. Specific primers (TGR-In primer set) targeted against T. grayi amplified a 525 bp fragment (MG234546, Additional file 1: Table S4) from tsetse fly gut sample (ID 237-51-00211-1-40-10, G. tachinoides, Additional file 1: Table S4). The fragment was sequenced and aligned with the corresponding fragment of genomic DNA from T. grayi ANR4 (JMRU01000589)

DNA. Overall, 96 of 241 (40\%) sampled tsetse flies were positive for trypanosomal ITS1 sequences in gut samples (Table 4 and Additional file 1: Table S1). The most prevalent Trypanosoma species in tsetse gut was $T$. grayi (56 flies), followed by $T$. congolense (40 flies) and T. brucei ssp. (14 flies) (Fig. 4a). The relative distribution of Trypanosoma species was similar in Dodeo and Gamba, and no significant differences were observed. $T$. grayi, T. congolense and T. brucei ssp. colonised mainly G. p. palpalis and G. m. submorsitans. The unidentified Glossina sp. harboured T. grayi and T. congolense. Among the 13 samples with DNA from more than one Trypanosoma species (Table 5), T. congolense occurred in 85\% (11 flies), T. grayi in $77 \%$ (10 flies) and T. brucei in 46\% (6 flies). The most frequent combination found was $T$. congolense with T. grayi (Table 5 and Additional file 1: Table S1).

Table 3 Percentage sequence identity matrix comparing T. grayi and T. theileri sequences from cattle blood samples

\begin{tabular}{|c|c|c|c|c|c|c|c|c|c|}
\hline & \multirow[b]{2}{*}{ T. grayi ANR4 } & \multicolumn{4}{|c|}{ Cattle } & \multicolumn{4}{|l|}{ T. theileri } \\
\hline & & $\overline{4^{a}}$ & $15^{\mathrm{a}}$ & $165^{a}$ & $361^{a}$ & Tthc $29^{\mathrm{b}}$ & SitaBip ${ }^{\text {b }}$ & Cow isolate ${ }^{b}$ & Tthb10 $(\mathrm{HQ664808)}$ \\
\hline Cattle $321^{\text {a }}$ (T. grayi, MG255205) & 98 & 63 & 62 & 54 & 53 & 47 & 47 & 60 & 53 \\
\hline T. grayi ANR4 (JMRU01000589) & & 64 & 63 & 54 & 53 & 47 & 48 & 61 & 54 \\
\hline Cattle $4^{\mathrm{a}}$ (T. theileri, MG255206) & & & 97 & 67 & 67 & 62 & 62 & 91 & 77 \\
\hline Cattle $15^{\mathrm{a}}$ (T. theileri, MG255207) & & & & 67 & 67 & 62 & 62 & 89 & 75 \\
\hline Cattle $165^{\mathrm{a}}$ (T. theileri, MG255208) & & & & & 99 & 97 & 82 & 66 & 56 \\
\hline Cattle $361^{a}$ (T. theileri, MG283143) & & & & & & 98 & 82 & 65 & 56 \\
\hline T. theileri Tthc29 ${ }^{\mathrm{b}}(\mathrm{HQ} 664818)$ & & & & & & & 83 & 61 & 57 \\
\hline T. theileri SitaBip1 ${ }^{\mathrm{b}}$ (HQ664843) & & & & & & & & 61 & 60 \\
\hline T. theileri cow isolate ${ }^{b}$ (JX853185) & & & & & & & & & 82 \\
\hline
\end{tabular}

${ }^{a}$ Cattle 4 and 15 were from the same herd sampled in Dodeo, cattle 165 was sampled in Alme, cattle 321 in Kontcha and cattle 361 in Gamba ${ }^{\mathrm{b}}$ T. theileri Tthc29 and T. theileri Tthc10 were isolated from cattle in Thailand [29]. T. theileri SitaBip1 was isolated from marsh buck in south Cameroon [61], identified as T. theileri [45] and the ITS1 sequence published by Garcia et al. [29]. T. theileri cow isolate was isolated from a cow in the USA [60] 
Table 4 Distribution of the Trypanosoma species in Glossina species in the gut. Total number of Trypanosoma species detected

\begin{tabular}{|c|c|c|c|c|c|c|}
\hline \multirow{2}{*}{$\begin{array}{l}\text { Study site } \\
\text { Glossina/Trypanosoma }\end{array}$} & \multicolumn{2}{|l|}{ Dodeo } & \multirow{2}{*}{$\begin{array}{l}\text { Alme } \\
\text { G. morsitans submorsitans }\end{array}$} & \multicolumn{2}{|l|}{ Gamba } & \multirow[t]{2}{*}{ Total } \\
\hline & G. palpalis palpalis & Glossina sp. & & G. morsitans submorsitans & G. tachinoides & \\
\hline T. grayi & 26 & 6 & 1 & 20 & 3 & 56 \\
\hline T. congolense & 27 & 2 & 0 & 11 & 0 & 40 \\
\hline T. brucei ssp. & 9 & 0 & 0 & 4 & 1 & 14 \\
\hline Positive flies ${ }^{a}$ & 52 & 6 & 1 & 37 & 3 & 96 \\
\hline Negative flies ${ }^{b}$ & 57 & 12 & 0 & 69 & 6 & 145 \\
\hline $\mathrm{N} 1100^{c}$ & 0 & 0 & 0 & 3 & 0 & 3 \\
\hline
\end{tabular}

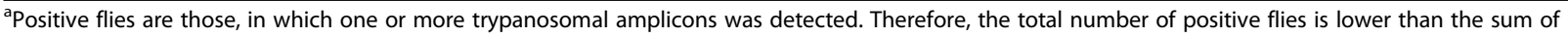
Trypanosoma detected in a fly species at a given location

' If no identified amplicon was detected, the fly was considered to be negative, including presence of NI100

${ }^{\mathrm{C}}$ Amplicon of $100 \mathrm{bp}$ detected and not identified. The corresponding sample was recorded as $\mathrm{NI}$ (non identified)

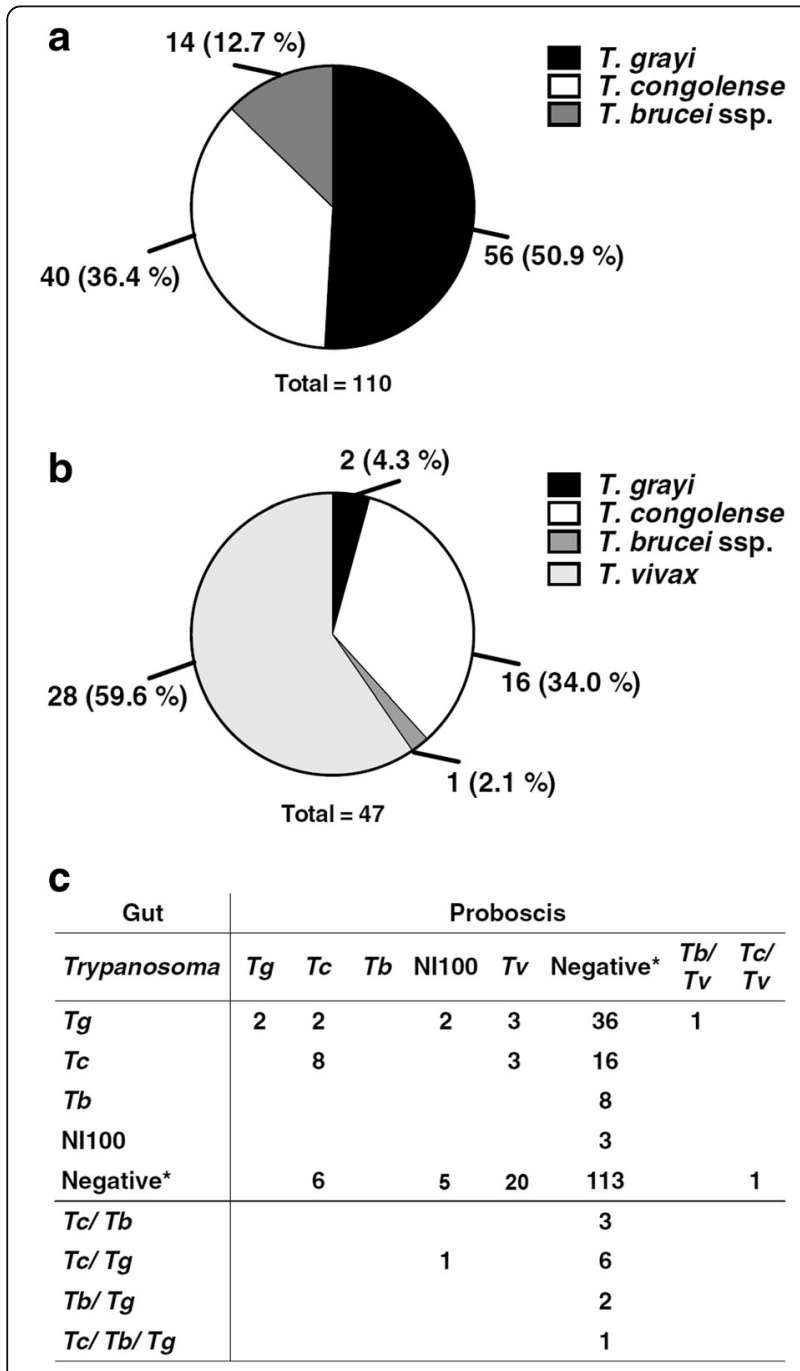

Fig. 4 Distribution of Trypanosoma species in tsetse flies. a Relative abundance of trypanosomal DNA by species in the gut. $\mathbf{b}$ Relative abundance of trypanosomal DNA by species in proboscis. c Correlation of trypanosomal DNA in gut and proboscis. Abbreviations: Tg, T. grayi; $T c, T$. congolense; $T b, T$. brucei ssp.; $T V$, $T$. vivax. If no amplicon was detected, the fly was considered to be negative

\section{Trypanosoma species in proboscis of tsetse flies}

The proboscis of tsetse flies were screened for trypanosomal DNA (Tables 6, 7 and Additional file 1: Table S2). Trypanosoma vivax was most prominent, followed by $T$. congolense (Fig. 4b). Surprisingly, two flies (G. m. submorsitans) from Gamba harboured T. grayi DNA.

Trypanosoma vivax and $T$. congolense colonised the proboscis of G. p. palpalis, G. m. submorsitans and G. tachinoides. In eight proboscis samples, NI100 was detected. Two of these samples were from Glossina sp., for which none of the identified trypanosomes was detected in the proboscis. Surprisingly, T. brucei DNA was detected in the proboscis of one G. p. palpalis, along with T. vivax DNA (Table 7 and Additional file 1).

\section{Concomitant colonisation of proboscis and gut by Trypanosoma species}

Trypanosoma vivax was equally distributed in Dodeo and Gamba as indicated by the number of tsetse fly proboscis carrying this parasite. Similarly, the abundance of T. grayi colonising the gut was almost the same at both locations, whereas $T$. congolense colonising the gut were significantly $\left(\chi_{(2)}^{2}=30.6, P<0.0001\right)$ more frequent in flies collected in Dodeo (G. p. palpalis). Overall, the distribution of the trypanosomes in different tsetse fly tissues showed the expected pattern for $T$. vivax and $T$. congolense (Fig. 4). Trypanosoma vivax colonised the proboscis exclusively, while $T$. congolense occurred in the gut and proboscis, with the highest prevalence found in the gut (Fig. 4c). Out of the 40 flies in which T. congolense DNA was detected in the gut, eight flies also contained $T$. congolense DNA in the proboscis. Interestingly, $T$. congolense DNA was detected in the proboscis of additional eight tsetse flies, for which no $T$. congolense DNA was found in the gut. Also no trypanosomal DNA was detected in the gut of the tsetse fly, in which T. brucei ssp. DNA was found in proboscis. Surprisingly, in two of the 56 flies containing T. grayi, DNA from this species was also found in the proboscis (Fig. 4c). NI100 was 
Table 5 Distribution of the Trypanosoma species in Glossina species in the gut. Distribution of concurrent colonisation

\begin{tabular}{|c|c|c|c|c|c|c|}
\hline Study site & Dodeo & & Alme & Gamba & & Tota \\
\hline Glossina/Trypanosoma & G. palpalis palpalis & Glossina sp. & G. morsitans submorsitans & G. morsitans submorsitans & G. tachinoides & \\
\hline T. congolense/brucei ssp. & 3 & 0 & 0 & 0 & 0 & 3 \\
\hline T. congolense/grayi & 4 & 2 & 0 & 1 & 0 & 7 \\
\hline T. brucei ssp./grayi & 1 & 0 & 0 & 0 & 1 & 2 \\
\hline T. congolense/grayi/brucei ssp. & 1 & 0 & 0 & 0 & 0 & 1 \\
\hline
\end{tabular}

detected in both tissues, but most frequently in proboscis (eight flies).

\section{Trypanosoma species in cattle}

To assess trypanosomal infections of cattle in the study areas, several herds with different breeds were screened, and blood from 392 animals was collected including 120 in Dodeo, 100 in Alme, 137 in Kontcha, and 35 in Gamba (Table 8 and Additional file 1: Table S3). In Dodeo, the majority of cattle were from the Gudali breed, whereas White Fulani was more prominent in Alme, Kontcha and Gamba. In contrast to the high prevalence of trypanosomes in tsetse flies (Tables 4, 5), only a few cattle were infected with trypanosomes (Table 8), most of them in Dodeo. Furthermore, ratios between the parasite species were different in flies and cattle, as shown for Dodeo in Fig. 5.

The animal pathogenic trypanosomes $T$. congolense, $T$. vivax and T. brucei ssp. were observed in 18/23 infections, four of these cattle were infected with $T$. theileri. An unexpected discovery was the case of T. grayi detected in one cow in Kontcha.

PCR products of non-identified origin were also amplified from four cattle blood samples when generic primers were used. In two of these animals, the products were similar to NI100 found in tsetse flies, whereas in the other two the products were about $250 \mathrm{bp}$. Sequencing of the latter indicated the source of DNA was derived from Bodonidae kinetoplastids, which are not parasitic in cattle [31].

\section{Influence of Trypanosoma infection on packed cell volume (PCV) of cattle blood}

Anaemia has been associated with the severity of disease in animals infected with trypanosomes. Therefore, the mean PCV of infected cattle $(24.1 \pm 5.7 \%)$ was compared to non-infected cattle $(27.1 \pm 4.9 \%)$ and was found to be significantly lower (t-test: $\left.t_{(390)}=-2.809, P=0.005\right)$ in infected animals (Fig. 6a). It should be noted that the mean PCV of non-infected animals (Table 9) from the two main breeds, Gudali and White Fulani, differed significantly (t-test: $\left.t_{(354)}=-2.786, P=0.006\right)$. Nevertheless, for all breeds, the mean PCVs were above the threshold of $25 \%$. The presence of several Trypanosoma species correlated with decreased PCVs of infected animals (Fig. 6b). The PCV was $23.0 \%, 23.8 \% \pm 6.2 \%$, and $22.1 \% \pm 6.8 \%$, respectively, for $T$. grayi, $T$. vivax and $T$. congolense. Interestingly, animals infected with $T$. brucei ssp. did not show a PCV below the threshold of $25 \%$. However, two animals with T. theileri infection had low PCVs (20 and 23\%), as was observed for those infected with bodonid kinetoplastids (23\%) (Fig. 6c).

\section{Discussion}

The main goal of this study was to identify the different Trypanosoma species colonising tsetse flies and causing trypanosomosis in cattle in Northern Cameroon. Here, we revealed the presence of several vector and parasite species in this area, including concurrent colonisation of tsetse flies with more than one Trypanosoma species. Our observations reveal urgent questions to be addressed

Table 6 Distribution of Trypanosoma species in Glossina species in proboscis. Total number of Trypanosoma species detected

\begin{tabular}{|c|c|c|c|c|c|c|}
\hline \multirow{2}{*}{$\begin{array}{l}\text { Study site } \\
\text { Glossina/ Trypanosoma }\end{array}$} & \multicolumn{2}{|l|}{ Dodeo } & \multirow{2}{*}{$\begin{array}{l}\text { Alme } \\
\text { G. morsitans submorsitans }\end{array}$} & \multicolumn{2}{|l|}{ Gamba } & \multirow[t]{2}{*}{ Total } \\
\hline & G. palpalis palpalis & Glossina sp. & & G. morsitans submorsitans & G. tachinoides & \\
\hline T. vivax & 13 & 0 & 0 & 14 & 1 & 28 \\
\hline T. congolense & 7 & 0 & 0 & 7 & 2 & 16 \\
\hline T. grayi & 0 & 0 & 0 & 2 & 0 & 2 \\
\hline T. brucei ssp. & 1 & 0 & 0 & 0 & 0 & 1 \\
\hline positive flies ${ }^{a}$ & 19 & 0 & 0 & 23 & 3 & 45 \\
\hline negative flies ${ }^{b}$ & 90 & 18 & 1 & 80 & 7 & 196 \\
\hline $\mathrm{N} 1100^{c}$ & 5 & 2 & 0 & 0 & 1 & 8 \\
\hline
\end{tabular}

apositive flies are those, in which one or more trypanosomal amplicons was detected. Therefore, the total number of positive flies is lower than the sum of Trypanosoma detected in a fly species at a given location

'If no identified amplicon was detected, the fly was considered to be negative, including presence of NI100

${ }^{\mathrm{c}}$ Amplicon of $100 \mathrm{bp}$ detected and not identified. The corresponding sample was recorded as NI (non identified) 
Table 7 Distribution of Trypanosoma species in Glossina species in proboscis. Distribution of concurrent colonisation

\begin{tabular}{|c|c|c|c|c|c|c|}
\hline \multirow{2}{*}{$\begin{array}{l}\text { Study site } \\
\text { Glossina/Trypanosoma }\end{array}$} & \multicolumn{2}{|l|}{ Dodeo } & \multirow{2}{*}{$\frac{\text { Alme }}{\text { G. morsitans submorsitans }}$} & \multicolumn{2}{|l|}{ Gamba } & \multirow[t]{2}{*}{ Total } \\
\hline & G. palpalis palpalis & Glossina sp. & & G. morsitans submorsitans & G. tachinoides & \\
\hline T. vivax/congolense & 1 & 0 & 0 & 0 & 0 & 1 \\
\hline T. vivax/brucei ssp. & 1 & 0 & 0 & 0 & 0 & 1 \\
\hline
\end{tabular}

regarding the infectivity and pathogenicity of various "non-pathogenic" trypanosomes.

\section{Distribution of Glossina species in the study area}

Three common species of tsetse flies were identified by their morphological characteristics and cox 1 sequences. Overall, G. m. submorsitans and G. p. palpalis were the predominant species identified. Consequently, they are likely to play a primary role in trypanosome transmission in the area. The distribution of the Glossina species varied in the different areas, reflecting the characteristics of the biotopes (Table 2). Glossina m. submorsitans dominated in the savannah of the Gamba area. Interestingly, Achukwi et al. [32] collected G. m. submorsitans in Guemnfiti (about $30 \mathrm{~km}$ north of Dodeo) and near

Table 8 Distribution of Trypanosoma species in cattle sampled at indicated study sites in northern Cameroon

\begin{tabular}{|c|c|c|c|c|c|c|}
\hline \multirow{2}{*}{$\begin{array}{l}\text { Study } \\
\text { site }\end{array}$} & \multirow{2}{*}{$\begin{array}{l}\text { Trypanosoma } \\
\text { species }\end{array}$} & \multicolumn{3}{|c|}{ Cattle breed } & \multirow{2}{*}{$\begin{array}{l}\text { Total } \\
(n)\end{array}$} & \multirow{2}{*}{$\begin{array}{l}\text { Infected } \\
(\%)^{\mathrm{a}}\end{array}$} \\
\hline & & $\begin{array}{l}\text { Gudali } \\
(n)\end{array}$ & $\begin{array}{l}\text { White Fulani } \\
(n)\end{array}$ & $\begin{array}{l}\text { Bokolodji } \\
(n)\end{array}$ & & \\
\hline \multirow[t]{6}{*}{ Dodeo } & T. congolense & 7 & & & 120 & 14.2 \\
\hline & T. brucei ssp & 3 & 1 & & & \\
\hline & T. vivax & 4 & & & & \\
\hline & T. theileri & 2 & & & & \\
\hline & Negative $^{b}$ & 100 & 3 & & & \\
\hline & $\mathrm{N} 1100^{c}$ & 1 & & & & \\
\hline \multirow[t]{3}{*}{ Alme } & T. theileri & & 1 & & 100 & 2.0 \\
\hline & T. vivax & & 1 & & & \\
\hline & Negative $^{b}$ & 3 & 95 & & & \\
\hline \multirow[t]{5}{*}{ Kontcha } & T. vivax & & 1 & & 137 & 1.5 \\
\hline & T. grayi & & 1 & & & \\
\hline & Negative $^{\mathrm{b}}$ & 32 & 99 & 4 & & \\
\hline & NI100 & & 1 & & & \\
\hline & Bodonidae $^{d}$ & 1 & 2 & & & \\
\hline \multirow[t]{3}{*}{ Gamba } & T. congolense & & 1 & & 35 & 5.7 \\
\hline & T. theileri & & & 1 & & \\
\hline & Negative $^{b}$ & & 24 & 9 & & \\
\hline
\end{tabular}

${ }^{a}$ Infected cattle include all animals in which DNA of an identified Trypanosoma $\mathrm{sp}$. was detected, but not those animals in which PCR products of unknown bodonid origin were observed

${ }^{\mathrm{b}}$ Negative cattle include all animals in which no identified Trypanosoma sp. was detected

'Amplicon of $100 \mathrm{bp}$ detected but not identified

${ }^{d} A$ PCR product indicating the presence of the Bodonidae was detected
Gamba. Their data suggested that these tsetse populations were not completely segregated. Although in that study the occurrence of trypanosomes was not analysed, it is likely that the parasites from these sites would also not be isolated populations.

Glossina P. palpalis was found exclusively in the Dodeo area, characterised by gallery forest. The G. palpalis group represent tsetse flies widely distributed in West and Central Africa [33-35]. Glossina p. palpalis is known to exhibit greater persistence to its location and to subsist in areas where anthropogenic developments have resulted in the disappearance of other species [36, 37].

Interestingly, in Dodeo another tsetse fly, for which no cox1 sequence was found in the databases, was collected, coexisting with G. p. palpalis. A preliminary phylogenetic analysis of cox 1 sequences placed this species close to the Glossina fusca group (data not shown), which would be consistent with a recent report on the occurrence of tsetse flies identified as G. fusca congolensis in Dodeo by Tongue et al. [38].

In Campo, a known focus of human trypanosomiasis in South Cameroon, Farikou et al. [33] found mainly G. p. palpalis $(94.7 \%)$ together with $G$. pallicera, $G$.

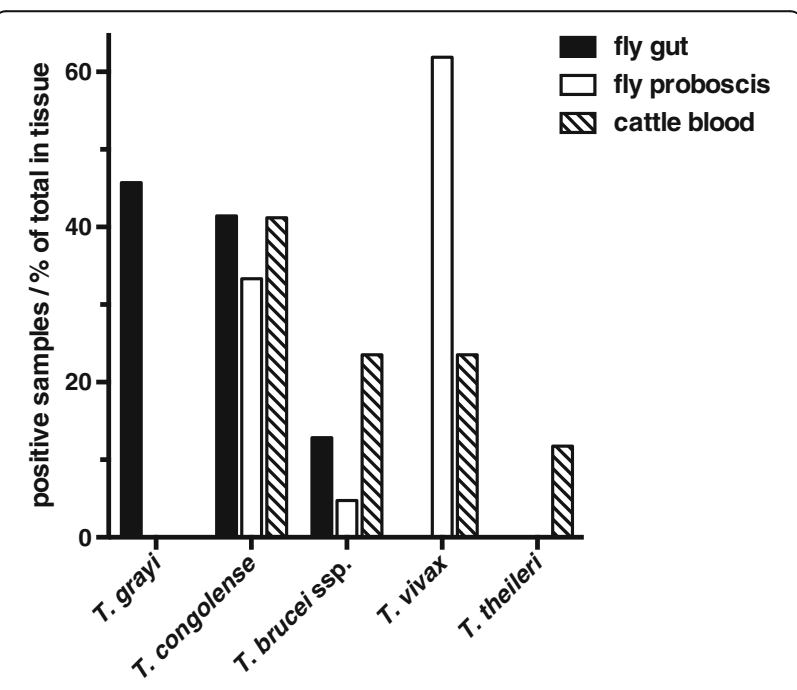

Fig. 5 Occurrence of Trypanosoma species in tsetse fly gut, proboscis and cattle blood from Dodeo. Only samples from which trypanosomal DNA was amplified were included. The percentage of each Trypanosoma species within the different tsetse fly tissues or cattle blood is displayed 

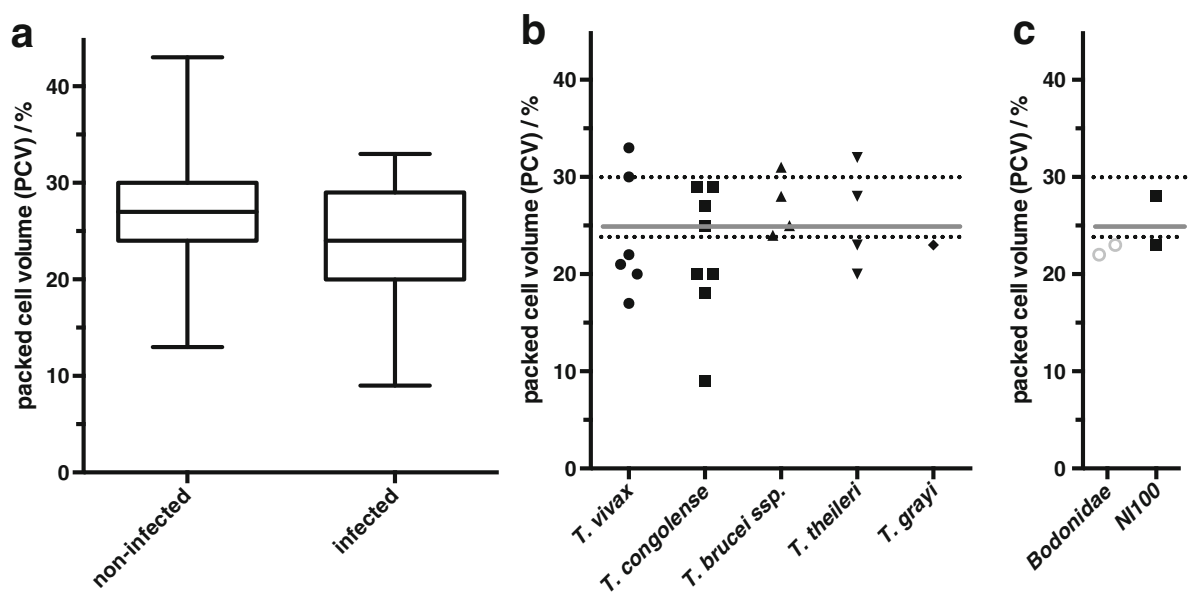

Fig. 6 Correlation of packed cell volume (PCV) in cattle blood with the presence of Trypanosoma DNA. a "Non-infected" vs "infected" animals. Cattle are considered "infected", if the Trypanosoma species as a source of a PCR product was confirmed, excluding bodonid and NI100 products. All other animals were grouped as "non-infected". The boxes indicate the corresponding 95\% confidence intervals. b PCVs of individual cattle, in which DNA of the indicated parasites were detected. Dotted lines indicate the $95 \%$ confidence intervals for PCV of animals, in which no trypanosomal DNA was detected; the grey line indicates the threshold PCV of 25\%. c PCVs of individual cattle, in which DNA of Bodonidae or NI100 were detected. Dotted lines indicate the 95\% confidence intervals for PCV of "non-infected" animals; the grey line indicates the threshold PCV of $25 \%$

caliginea and G. nigrofusca, which were also collected in this forestry area. While cox 1 sequences are available for G. pallicera and G. caliginea, no such information is accessible for G. nigrofusca and several other G. fusca species at present. Therefore, it cannot be excluded that the unidentified Glossina sp. from Dodeo may represent one of these G. fusca species.

\section{Distribution of Trypanosoma species in tsetse flies}

The variety of amplicons identified in this study reveals the full diversity of trypanosomes in Northern Cameroon, which hitherto was poorly understood. The overall percentage of tsetse fly gut samples positive for the presence of Trypanosoma was high compared to previous studies in other areas of West and Central Africa, where it ranged from 6 to $10 \%$ [39-41]. These findings could be attributed to differences in the study sites, season and identification methods used. In this study, trypanosomal DNA was detected in $40 \%$ of tsetse fly gut and 19\% of tsetse fly proboscis samples. The frequencies of concurrent colonisation by two or more Trypanosoma species in tsetse fly gut samples can be explained by random uptake of these most abundant parasites with the blood meals by a fly already colonised by the other Trypanosoma species. Therefore, the data (Tables 4,5) do not provide evidence for competition or co-operation of these Trypanosoma species in gut colonisation.

In $5 \%$ of all flies, an unidentified PCR product (NI100) was obtained reproducibly. However, attempts at sequencing showed heterogeneous results and the source of these PCR products remained uncertain, and the data are not considered further.

Overall, $T$. grayi was the most prevalent trypanosome in tsetse fly gut samples (Table 4). Only a few field surveys have investigated the occurrence of T. grayi in tsetse flies, e.g. in the Democratic Republic of Congo [42] and the Central African Republic [43]. Originally isolated from the crocodile, Crocodilus niloticus, $T$. grayi has been considered a parasite of reptiles [44-47]. This seems to fit the consistent reports of this parasite in riverine species, in

Table 9 Mean packed cell volume (PCV) of cattle sampled at study sites in northern Cameroon

\begin{tabular}{|c|c|c|c|c|c|}
\hline \multirow[t]{2}{*}{ Cattle breed } & \multicolumn{2}{|l|}{ Infected cattle ${ }^{a}$} & \multicolumn{2}{|c|}{ Non-infected cattle ${ }^{b}$} & \multirow{2}{*}{$\begin{array}{l}\text { Prevalence } \\
(\%)\end{array}$} \\
\hline & No. of samples & Mean PCV (\%) & No. of samples & Mean PCV (\%) & \\
\hline Total & 23 & $24.1 \pm 5.7$ & 369 & $27.1 \pm 4.9$ & 5.9 \\
\hline Gudali & 16 & $24.8 \pm 5.0$ & 135 & $26.2 \pm 5.1$ & 10.6 \\
\hline White Fulani & 6 & $22.5 \pm 8.0$ & 221 & $27.7 \pm 4.6$ & 2.6 \\
\hline Bokolodji & 1 & 23 & 13 & $25.5 \pm 5.8$ & 7.1 \\
\hline
\end{tabular}

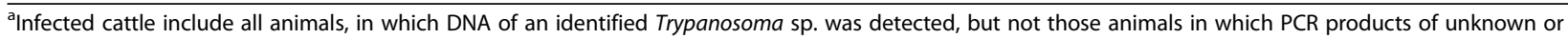
bodonid origin were observed

${ }^{\mathrm{b}}$ Non-infected cattle include all animals in which no identified Trypanosoma sp. was detected 
particular, G. palpalis, feeding on reptiles [41, 42]. Therefore, it was surprising to find $T$. grayi to be the most frequent trypanosome also in G. m. submorsitans.

To be transmitted to mammalian hosts, salivarian trypanosomes have to undergo a successive maturation process and develop into metacyclic trypomastigotes in either salivary glands or proboscis, depending on the species [8]. Our data (Fig. 4) showed a correlation between Trypanosoma species found in the gut and proboscis of G. p. palpalis, G. m. submorsitans and G. tachinoides, but not in the non-identified Glossina sp. collected in Dodeo. This might suggest that this Glossina sp. is not a good vector for T. congolense or T. vivax. However, due to the low number of flies analysed we cannot exclude Glossina sp. as a vector since we found only two flies with $T$. congolense in the gut and have to consider that not all gut colonisations lead to mature metacyclic trypomastigotes.

Trypanosoma vivax and T. grayi were equally distributed in Dodeo and Gamba, whereas T. congolense were more frequent in flies collected in Dodeo. From the 40 flies, which were colonised by $T$. congolense in the gut, eight flies were also positive in the proboscis, suggesting that the parasites had matured into the infective stage in these eight but not in the other 32 flies. Notably, in G. $p$. palpalis we observed a lower rate of $T$. congolense maturation (seven positive proboscis samples compared to 27 positive gut samples) than in G. m. submorsitans (seven positive proboscis samples compared to 11 positive gut samples) collected in Gamba. This observation is in agreement with a superior vector capacity of G. $m$. submorsitans for T. congolense than G. p. palpalis, as indicated in previous studies [48-50].

Strikingly, in $50 \%$ of all flies containing $T$. congolense in their proboscis, the parasite was not detected in the gut. This finding is consistent with the notion that in these cases the mid-gut colonisation by $T$. congolense has been cleared by the tsetse flies, whereas the proboscis colonisation has persisted, as has been reported previously $[49,51,52]$. Nevertheless, surveys on the prevalence of $T$. congolense trypanosomes often do not appear to take this into account, just analysing the proboscis of mid-gut-positive flies to determine infection rates. This could lead to an underestimation of the prevalence of tsetse flies carrying infective $T$. congolense.

Trypanosoma vivax was only detected in proboscis samples, but not in gut samples. This result is in agreement with the life-cycle of $T$. vivax, which in general only colonises mouthparts of tsetse flies, but not the gut [9], although a few studies detected T. vivax also in midgut $[16,34]$.

All Glossina species collected in this study were susceptible to colonisation with $T$. grayi. This parasite has been described to colonise the mid- and hindgut of the tsetse flies exclusively and to be transmitted via faeces [44-47]. Strikingly, in two cases we detected T. grayi also in the proboscis of G. m. submorsitans. While this could originate from a recently infected blood meal, it should be noted that in only one of these two flies a recent blood meal was observed. Based on this, it appears $T$. grayi may also be able to migrate from the gut to the mouthparts of the tsetse fly, although only at low frequency. If present in proboscis, $T$. grayi might also be transmitted via a blood meal. Even if this originates from recently infected blood meals, it would indicate that $T$. grayi might also be mechanically transmitted. This would be consistent with the detection of T. grayi in cattle blood. This raises the interesting question whether these trypanosomes represent a new strain with different life-cycle and host range than the 'known' T. grayi. Currently, for a phylogenetic comparison, limited sequence data are available for three different $T$. grayi subclades [46]. The comparison with the only other available ITS1 sequence (strain ANR4) revealed only a few differences, which are not sufficient for such a conclusion, especially as the number of cases is low. Further investigations need to be undertaken to investigate strain differentiation and possible transmission pathways for $T$. grayi in this region.

\section{Trypanosoma infections in cattle}

The relatively high proportion of animal pathogenic trypanosomes found in tsetse flies in the present study suggests a high risk of trypanosomosis for livestock in the areas. The overall prevalence rate found in cattle was only about $6 \%$. However, looking at the different localities the rates varied between 1.5\% (Kontcha) and 14.2\% (Dodeo) (Table 8), which was similar to those reported from cattle herds investigated in 2008 in the Faro division (14.3\%) [18] and 2014 at several ranches in Mayo Rey (9.0\%) [53]. It should be noted that in an earlier study (2001 through 2002) from sites in Faro et Deo and Vina about $40 \%$ cattle were found to be infected [11]. Although these previous studies used microscopy instead of PCR to detect the parasites, together these studies suggest a decline in trypanosomal infections in these areas over the years. This progressive decrease of trypanosomosis could be explained by an increased adoption rate of tsetse control techniques by livestock farmers. Currently, there appear to be ongoing epidemiological surveillance and updated control activities in the Adamawa region of Cameroon. These have involved screens baited with insecticides, spraying of cattle as live baits with pyrethroids (mainly acaricides) and improved use of trypanocidal drugs, which principally targets bovine trypanosomosis.

The three major known pathogenic Trypanosoma species found in tsetse flies were also detected in cattle, but 
the ratios between the parasite species were different in flies and cattle. Comparing the relative prevalence in tsetse proboscis with that in cattle blood, $T$. congolense seems to be more successfully transmitted than $T$. vivax. When analysing the situation in tsetse gut with cattle infections, T. brucei ssp. appears to be more successful in completing the life-cycle from gut to host blood. Since the number of infected cattle is low, inevitably conclusive correlations cannot be obtained. To investigate the transmission efficiencies of Trypanosoma species, an experimental study monitoring the different stages in tsetse flies and natural infection to livestock would be necessary.

Surprisingly, T. grayi was detected in one cow. This is remarkable since previous trials to infect mammals with T. grayi were not successful, as discussed by Hoare [3]. Moreover, $T$. grayi has only been found in reptiles and not from mammals [44]. At present, we cannot exclude that the T. grayi parasites circulating in the study area represent a strain changing host range as discussed above, in particular as it also has been detected in tsetse proboscis. To test this hypothesis, further studies are necessary to characterise $T$. grayi strains in these areas. This includes isolation of these parasites and testing Koch's postulates for pathogens by infection experiments with mammals.

Besides the trypanosomes found in tsetse flies, T. theileri infections were detected in four of the 23 Trypanosoma-infected cattle. This observation supports the notion that non-tsetse vector(s) transmit $T$. theileri, such as the Tabanidae [54] and ticks [55]. It should be noted that the ITS1 sequences revealed that two distinct $T$. theileri lineages are circulating in the study area (Table 3). A phylogenetic study of the globally distributed $T$. theileri by Garcia et al. [29] described two main clades (I and II), which were further divided into several branches. The T. theileri lineages identified in this study could be assigned to clades I and IIB. Similar cocirculation of diverse $T$. theileri clades within one area had also been observed in Thailand [29].

On average, cattle with trypanosomal DNA in their blood had PCV values below a threshold of $25 \%$. This is in agreement with previous studies $[56,57]$ and the notion that anaemia plays a key role in determining the severity of the infection in animals infected with trypanosomes [53]. In some cases, normal average PCV values in infected cattle were reported [58, 59], which was attributed to increased individual levels of definitive host resistance, better feeding in some cattle, or to a good body condition. It was observed here that $50 \%$ of cattle infected with $T$. congolense had PCV values below the $25 \%$ threshold. This is not surprising, as T. congolense is known to be the most pathogenic of these parasites in cattle. On that note, attention should be drawn to the cases of $T$. grayi, and the Bodonidae detected in this study. Their occurrence in cattle blood correlated with low PCV values similar to those observed for $T$. congolense infections. This suggests that they are potential pathogens, even though these have not been considered as pathogenic to mammals before [60]. Interestingly, animals infected with $T$. theileri parasites resembling clade IIB [29] had similarly low PCV values, whereas animals infected with $T$. theileri belonging to clade I both had normal PCV values. The observation brings up the question of changing pathogenicity of strains of parasites within one species. Obviously, it remains unknown, whether the low PCVs observed was due to the presence of these kinetoplastids or the anaemic status had other reasons, such as malnutrition or tick-borne pathogens. Along with this line, it is possible that a general poor health status promoted susceptibility to infections by these otherwise nonpathogenic parasites.

\section{Conclusion}

The present study reveals that the diversity of trypanosomes in Northern Cameroon is more complex than previously thought. The burden of trypanosomosis could vary drastically between locations, as has been indicated by high infection rates in Dodeo compared to the other study sites. Besides the known pathogenic parasites, $T$. grayi was widely spread in the gut of tsetse flies. Unexpectedly, in a few cases, T. grayi appears to also colonise the mouthparts. Moreover, mammals should not be excluded as possible hosts for T. grayi, as it has been detected in cattle. Furthermore, it was observed that in unexpected cases T. theileri, T. grayi and bodonid infections correlated with low PCVs in cattle. These observations indicate that evolution of these parasites' life-cycles could have caused them to become pathogenic at least in cattle with suboptimal health status. Thus, applying detailed analysis including sequencing of PCR products is necessary for monitoring the diversity of parasites, which is essential for the detection of changing pathogenicity of trypanosomes. In the case of $T$. theileri, which are transmitted by biting insects other than tsetse flies, it will be necessary to expand vector control and monitoring studies beyond tsetse flies.

\section{Additional files}

\footnotetext{
Additional file 1: Table S1. Data for tsetse flies gut sample analysis. Sampling sites, ID code, Glossina species, PCR analysis with ITS1 primers (Table 1), accession numbers of sequences. Band sizes were determined by agarose gel electrophoresis and therefore, the sizes given are approximate. Based on sequences and data obtained in this study, size heterogeneity occurs for several species. The size ranges, in which we have to consider the corresponding Trypanosoma species are indicated in a separate column (expected). Table S2. Data for tsetse flies proboscis sample analysis. Sampling sites, ID code, flies species, PCR analysis with
} 
ITS1 primers (Table 1), accession numbers of sequences. Band sizes were determined by agarose gel electrophoresis and therefore, the sizes given are approximate. Based on sequences and data obtained in this study, size heterogeneity occurs for several species. The size ranges, in which we have to consider the corresponding Trypanosoma species are indicated in a separate column (expected). Table S3. Data for cattle blood sample analysis. Sampling sites, herd ID code, ID code, cattle breed, PCV, PCR analysis with ITS1 primers (Table 1), accession numbers of sequences. Band sizes were determined by agarose gel electrophoresis and therefore, the sizes given are approximate. Based on sequences and data obtained in this study, size heterogeneity occurs for several species. The size ranges, in which we have to consider the corresponding Trypanosoma species are indicated in a separate column (expected). Table S4. Nucleic acid sequences generated in this study and their accession numbers. (XLS $169 \mathrm{~kb})$

Additional file 2: Figure S1. Alignment showing the identification of T. grayi. The ITS1 fragment of 314 bp length was amplified with ITS1-InF and ITS1-InR from a tsetse fly gut sample (ID 237-51-00211-1-40-10, G. tachinoides, Additional file 1: Table S4), was subcloned, sequenced as described under Methods and the 314 bp sequence (MG234546) was then aligned against the corresponding fragment of genomic DNA from T. grayi ANR4 (JMRU01000589) as described in Methods. (PDF $13 \mathrm{~kb}$ )

\section{Abbreviations}

BLAST: Basic Local Alignment Search Tool; cox1: cytochrome c oxidase 1; ITS1: Internal transcribed spacer 1; PCV: Packed cell volume

\section{Acknowledgements}

We dedicate this publication to late Professor Jonathan Andrew Nok from Ahmadu Bello University, Zaria, Nigeria, who untimely passed away while this publication was in press. He has been a fundamental supporter and collaborator in our work. Moreover, Prof. Jonathan Andrew Nok has been a really outstanding scientists on Neglected Tropical Diseases in Africa and beyond. Without his continuous support and always motivating drive for numerous young scientists from Africa, many scientists and their projects would not have made it to the point where they are now. This holds in particular for this project and these authors, three former or present PhD students (SCHN, JSW and TTG) and two current direct co-Pls (SK and MDA) are personally particularly indebted to Professor Jonathan Andrew Nok. We thank Samuel Abah, Abakar, Frederik, Hamman, Youssouf Mfopit, Achille Paguem and the Lamido de Dodeo for valuable support in the field work, the herdsmen from Dodeo, Dagoum, Kontcha, Alme and Gamba for support in sample collection from their cattle. We are grateful to the Chief of centre responsible for the Veterinary Research laboratory, IRAD Wakwa, Ngaoundéré, for providing the enabling environment in which a good part of this work was undertaken. We are thankful to Gloria D. Chechet, Frank Dietz and Stephen S. Shaida for methodological advice, Mario Waespy and Federico Paroni for fruitful discussions and advice, Petra Berger for expert technical support in field work and laboratory, and Wendy Gibson for the kind donation of T. grayi genomic DNA.

\section{Funding}

Financial support for the project came from Deutscher Akademischer Austauschdienst (DAAD; sandwich program stipend to SCHN, CN_A/12/ 97080; subject-related partnership between University Bremen and University Ngaoundéré), Ministry of public health (Cameroon), funded field work and travel grant to SCHN), from Deutsche Forschungsgemeinschaft (DFG; project grants to SK, Ke428/8-1, Ke428/10-1), from International Atomic Energy Agency (IAEA; travel funds to SK), and from Africa Centre of Excellence for Neglected Tropical Diseases and Forensic Biotechnology (ACE-NTDFB; sponsoring training workshops on collection and dissection of tsetse flies).

\section{Availability of data and materials}

The data sets supporting the conclusions of this article are included within the article and its additional files. The sequences generated in this study were submitted to the GenBank database under the accession numbers MG234534-MG234551, MG255201-MG255221 and MG283141-MG283146 (see Additional file 1: Table $\$ 4$ for details).

\section{Authors' contributions}

SCHN collected samples, performed analysis by PCR and sequencing, designed specific primers for T. grayi, drafted and wrote the manuscript. JSW performed analysis by PCR and sequencing and wrote the manuscript. ENB supervised the PhD proposal, obtained ethical clearance, and facilitated the support of traditional and administrative authorities. TTG designed specific primers for trypanosomes and tsetse flies, gave advice for the development of PCR analysis, and contributed to drafting the manuscript. SK designed the project, supervised the laboratory experiments, and wrote the manuscript. MDA designed the project, supervised the field work and laboratory experiments, and wrote the manuscript. All authors read and approved the final manuscript.

\section{Ethics approval}

The study was conducted with the approval of the Ministère de l'élévage des pêches et des industries animales (MINEPIA) and by Mission spéciale d'éradication des glossines (MSEG) at the National and district levels, as well as the district veterinary officers in each of the study districts.

\section{Consent for publication}

Not applicable.

\section{Competing interests}

The authors declare that they have no competing interests.

\section{Publisher's Note}

Springer Nature remains neutral with regard to jurisdictional claims in published maps and institutional affiliations.

\section{Author details}

${ }^{1}$ Department of Biological Sciences, University Ngaoundéré, P.O. Box 454, Ngaoundéré, Cameroon. ${ }^{2}$ Ministry of Public Health, Regional Hospital of Ngaoundéré, Ngaoundéré, Cameroon. ${ }^{3}$ Centre for Biomolecular Interactions Bremen, Department of Biology and Chemistry, University Bremen, 28334 Bremen, Germany. ${ }^{4}$ Africa Centre of Excellence for Neglected Tropical Diseases and Forensic Biotechnology, Ahmadu Bello University, Zaria, Nigeria. ${ }^{5}$ Department of Biology, Ahmadu Bello University, Zaria, Nigeria. ${ }^{6}$ TOZARD Research Laboratory, P.O. Box 59, Bambili-Tubah, Bamenda, Cameroon.

Received: 31 May 2017 Accepted: 15 November 2017 Published online: 29 December 2017

\section{References}

1. World Health Organization. Control and surveillance of human African trypanosomiasis. Geneva: World Health Organization; 2014.

2. Hu C, Aksoy S. Innate immune responses regulate trypanosome parasite infection of the tsetse fly Glossina morsitans morsitans. Mol Microbiol. 2006; 60:1194-204.

3. Hoare CA. Studies on Trypanosoma grayi. Trans R Soc Trop Med Hyg. 1929; 23:39-56.

4. Krafsur ES. Tsetse flies: genetics, evolution, and role as vectors. Infect Genet Evol. 2009:9:124-41.

5. Baldacchino F, Muenworn V, Desquesnes M, Desoli F, Charoenviriyaphap T, Duvallet G. Transmission of pathogens by Stomoxys flies (Diptera, Muscidae): a review. Parasite. 2013;20:26

6. Solano P, Delafosse SA. Trypanosoma congolense chez différentes espèces de taons (Diptera: Tabanidae) au Burkina Faso. Revue Elev Méd Vét Pays Trop. 1995;48:145-6.

7. Gooding RH, Krafsur ES. Tsetse genetics: contributions to biology, systematics, and control of tsetse flies. Annu Rev Entomol. 2005;50:101-23.

8. Dyer NA, Rose C, Ejeh NO, Acosta-Serrano A. Flying tryps: survival and maturation of trypanosomes in tsetse flies. Trends Parasitol. 2013;29:188-96.

9. Moloo SK, Gray MA. New observations on cyclical development of Trypanosoma vivax in Glossina. Acta Trop. 1989;46:167-72.

10. Mamoudou A, Zoli A, Van den Bossche P, Delespaux V, Cuisance D, Geerts $S$. Half a century of tsetse and animal trypanosomosis control on the Adamawa plateau in Cameroon. Revue Elev Méd Vét Pays Trop. 2009;62:33-8.

11. Tanenbe C, Gambo H, Musongong GA, Boris O, Achukwi MD. Prévalence de la trypanosomose bovine dans les départements du Faro et Déo, et de la Vina au Cameroun: bilan de vingt années de lutte contre les glossines. Revue Elev Méd Vét Pays Trop. 2010;63:63-9. 
12. Mamoudou A, Zoli A, Mbahin N, Tanenbe C, Bourdanne, Clausen PH, et al. Prevalence and incidence of bovine trypanosomosis on the Adamaoua plateau in Cameroon 10 years after the tsetse eradication campaign. Vet Parasitol. 2006;142:16-22

13. Njiokou F, Laveissière C, Simo G, Nkinin S, Grébaut P, Cuny G, et al. Wild fauna as a probable animal reservoir for Trypanosoma brucei gambiense in Cameroon. Infect Genet Evol. 2006;6:147-53.

14. Njiokou F, Nimpaye H, Simo G, Njitchouang GR, Asonganyi T, Cuny G, et al. Domestic animals as potential reservoir hosts of Trypanosoma brucei gambiense in sleeping sickness foci in Cameroon. Parasite. 2010;17:61-6.

15. Simo G, Mbida Mbida JA, Ebo'o Eyenga V, Asonganyi T, Njiokou F, Grébaut $P$. Challenges towards the elimination of human African trypanosomiasis in the sleeping sickness focus of campo in southern Cameroon. Parasit Vectors. 2014;7:374.

16. Simo G, Fongho P, Farikou O, Ndjeuto-Tchouli PIN, Tchouomene-Labou J, Njiokou F, et al. Trypanosome infection rates in tsetse flies in the "silent" sleeping sickness focus of Bafia in the Centre region in Cameroon. Parasit Vectors. 2015;8:528.

17. Mamoudou A, Delespaux V, Chepnda V, Hachimou Z, Andrikaye JP, Zoli A, et al. Assessment of the occurrence of trypanocidal drug resistance in trypanosomes of naturally infected cattle in the Adamaoua region of Cameroon using the standard mouse test and molecular tools. Acta Trop. 2008;106:115-8.

18. Achukwi MD, Musongong GA. Trypanosomosis in the Doayo/Namchi (Bos taurus) and zebu white Fulani (Bos indicus) cattle in Faro division, North Cameroon. J App Biosc. 2009;15:807-14.

19. Mpouam SE, Achukwi MD, Feussom Kameni JM, Ouedraogo GA. Serological and parasitological prevalence of bovine trypanosomosis in small holder farms of the Vina division, Adamawa region of Cameroon. J Parasitol Vector Biol. 2011;3:44-51.

20. Mamoudou A, Payne VK, Sevidzem SL. Hematocrit alterations and its effects in naturally infected indigenous cattle breeds due to Trypanosoma spp. on the Adamawa plateau - Cameroon. Vet World. 2015;8:813-8.

21. Gibson WC, Dukes P, Gashumba JK. Species-specific DNA probes for the identification of African trypanosomes in tsetse flies. Parasitology. 1988;97(1): 63-73.

22. Masiga DK, Smyth AJ, Hayes P, Bromidge TJ, Gibson WC. Sensitive detection of trypanosomes in tsetse flies by DNA amplification. Int J Parasitol. 1992;22: 909-18.

23. Geysen D, Delespaux V, Geerts S. PCR-RFLP using SSU-rDNA amplification as an easy method for species-specific diagnosis of Trypanosoma species in cattle. Vet Parasitol. 2003;110:171-80.

24. Adams ER, Malele II, Msangi AR, Gibson WC. Trypanosome identification in wild tsetse populations in Tanzania using generic primers to amplify the ribosomal RNA ITS1 region. Acta Trop. 2006;100:103-9.

25. National Institute of Statisitics, Cameroon. The population and housing census of Cameroon. Available from: http://cameroon.opendataforafrica.org/ rfdefze/census-data. Accessed on 22 Mar 2017

26. Koné N, Bouyer J, Ravel S, Vreysen MJB, Domagni KT, Causse S, et al. Contrasting population structures of two vectors of African trypanosomoses in Burkina Faso: consequences for control. PLoS Negl Trop Dis. 2011;5:e1217.

27. Leak S, Ejigu D, Vreysen M. Collection of entomological baseline data for tsetse area-wide integrated pest management programmes. Geneva: Food and Agriculture Organization of the United Nations; 2008.

28. Dyer NA, Lawton SP, Ravel S, Choi KS, Lehane MJ, Robinson AS, et al. Molecular phylogenetics of tsetse flies (Diptera: Glossinidae) based on mitochondrial (COI, 16S, ND2) and nuclear ribosomal DNA sequences, with an emphasis on the palpalis group. Mol Phylogenet Evol. 2008;49:227-39.

29. Garcia HA, Rodrigues AC, Martinkovic F, Minervino AHH, Campaner M, Nunes VLB, et al. Multilocus phylogeographical analysis of Trypanosoma (Megatrypanum) genotypes from sympatric cattle and water buffalo populations supports evolutionary host constraint and close phylogenetic relationships with genotypes found in other ruminants. Int J Parasitol. 2011; 41:1385-96.

30. Garcia HA, Kamyingkird K, Rodrigues AC, Jittapalapong S, Teixeira MMG, Desquesnes $\mathrm{M}$. High genetic diversity in field isolates of Trypanosoma theileri assessed by analysis of cathepsin L-like sequences disclosed multiple and new genotypes infecting cattle in Thailand. Vet Parasitol. 2011;180:363-7.

31. Dolezel D, Jirků M, Maslov DA, Lukes J. Phylogeny of the bodonid flagellates (Kinetoplastida) based on small-subunit rRNA gene sequences. Int I Sys Evol Microbiol. 2000;50(5):1943-51.
32. Achukwi MD, Gillingwater J, Michel Njan Nloga A, Simo G. Lack of evidence for sufficiently isolated populations of Glossina morsitans submorsitans on the Adamawa plateau of Cameroon following geometric morphometric analysis. Adv Entomol. 2013;01:1-7.

33. Farikou O, Njiokou F, Mbida Mbida JA, Njitchouang GR, Djeunga HN, Asonganyi T, et al. Tripartite interactions between tsetse flies, Sodalis glossinidius and trypanosomes - an epidemiological approach in two historical human African trypanosomiasis foci in Cameroon. Infect Genet Evol. 2010;10:115-21.

34. Simo G, Silatsa B, Flobert N, Lutumba P, Mansinsa P, Madinga J, et al. Identification of different trypanosome species in the mid-guts of tsetse flies of the Malanga (Kimpese) sleeping sickness focus of the Democratic Republic of Congo. Parasit Vectors. 2012;5:201.

35. Kaba D, Zacarie T, M'pondi AM, Njiokou F, Bosson-Vanga H, Kröber T, et al. Standardising visual control devices for tsetse flies: central and west African species Glossina palpalis palpalis. PLoS Negl Trop Dis. 2014;8:e2601.

36. Reid RS, Kruska RL, Deichmann U, Thornton PK. Human population growth and the extinction of the tsetse fly. Agric Ecosys Env. 2000;77:227-36.

37. Mahama C, Hussein ZAM, Abavana M, Koné A, Sidibe I, Geerts S. Tsetse and trypanosomoses in Ghana in the twentieth century: a review. Revue Elev Méd Vét Pays Trop. 2003;56:27-32.

38. Tongue LK, Acapovi-Yao GL, Kaba D, Abah S, Nchiwan EN. Updating tsetse distribution: presence of Austenina subgenus group in Northern Cameroon. J Basic Appl Res Int. 2015;7:66-72.

39. Adams ER, Hamilton PB, Malele II, Gibson WC. The identification, diversity and prevalence of trypanosomes in field caught tsetse in Tanzania using ITS-1 primers and fluorescent fragment length barcoding. Infect Genet Evol. 2008;8:439-44.

40. Bouyer J, Koné N, Bengaly Z. Dynamics of tsetse natural infection rates in the Mouhoun River, Burkina Faso, in relation with environmental factors. Front Cell Infect Microbiol. 2013;3:47.

41. Morlais I, Grébaut P, Bodo JM, Djoha S, Cuny G, Herder S. Detection and identification of trypanosomes by polymerase chain reaction in wild tsetse flies in Cameroon. Acta Trop. 1998;70:109-17.

42. Bourzat D, Gouteux JP. Données préliminaires sur le contact glossines-petits ruminants dans le massif forestier du Mayombe, Congo. Revue Elev Méd Vét Pays Trop. 1990;43:199-206.

43. Gouteux JP, Gibson WC. Detection of infections of Trypanosoma grayi in Glossina fuscipes fuscipes in the Central African Republic. Ann Trop Med Parasitol. 1996;90:555-7.

44. Minter-Goedbloed E, Leake CJ, Minter DM, McNamara J, Kimber C, Bastien P, et al. Trypanosoma varani and T. grayi-like trypanosomes: development in vitro and in insect hosts. Parasitol Res. 1993;79:329-33.

45. Hamilton PB, Adams ER, Njiokou F, Gibson WC, Cuny G, Herder S. Phylogenetic analysis reveals the presence of the Trypanosoma cruzi clade in African terrestrial mammals. Infect Genet Evol. 2009:9:81-6.

46. Fermino BR, Viola LB, Paiva F, Garcia HA, de Paula CD, Botero-Arias R, et al. The phylogeography of trypanosomes from south American alligatorids and African crocodilids is consistent with the geological history of south American river basins and the transoceanic dispersal of Crocodylus at the Miocene. Parasit Vectors. 2013;6:313.

47. Kelly S, Ivens A, Manna PT, Gibson W, Field MC. A draft genome for the African crocodilian trypanosome Trypanosoma grayi. Sci Data. 2014;1:140024.

48. Maudlin I, Welburn SC. Maturation of trypanosome infections in tsetse. Exp Parasitol. 1994;79:202-5.

49. Ravel S, Grébaut P, Mariani C, Jamonneau V, Cuisance D, Gooding RH, et al. Monitoring the susceptibility of Glossina palpalis gambiensis and $G$. morsitans morsitans to experimental infection with savannah-type Trypanosoma congolense, using the polymerase chain reaction. Ann Trop Med Parasitol. 2004;98:29-36

50. Reifenberg JM, Cuisance D, Frézil JL, Cuny G, Duvallet G. Comparison of the susceptibility of different Glossina species to simple and mixed infections with Trypanosoma (Nannomonas) congolense savannah and riverine forest types. Med Vet Entomol. 1997;11:246-52.

51. Jordan AM. The hosts of Glossina as the main factor affecting trypanosome infection rates of tsetse flies in Nigeria. Trans R Soc Trop Med Hyg. 1965;59: 423-31.

52. Lehane MJ, Msangi AR, Whitaker CJ, Lehane SM. Grouping of trypanosome species in mixed infections in Glossina pallidipes. Parasitology. 2000;120(6):583-92.

53. Mamoudou A, Njanloga A, Hayatou A, Suh PF, Achukwi MD. Animal trypanosomosis in clinically healthy cattle of north Cameroon: epidemiological implications. Parasit Vectors. 2016;9:206. 
54. Böse R, Friedhoff KT, Olbrich S, Büscher G, Domeyer I. Transmission of Trypanosoma theileri to cattle by Tabanidae. Parasitol Res. 1987;73:421-4.

55. Aeschlimann A, Burgdorfer W, Matile H, Péter O, Wyler R. Aspects nouveaux du rôle de vecteur joué par Ixodes ricinus L. en Suisse. Note préliminaire. Acta Trop. 1979;36:181-91.

56. Kenaw B, Dinede G. Trypanosomosis and its associated risks in cattle population of Dangur District of Benishangul Gumuz regional state, western Ethiopia. Eur J App Sci. 2015;7:291-6.

57. Dinede G, Aki A. Epidemiology of cattle trypanosomosis and associated anaemia in Mandura district. Nat Sci. 2016;14:85-90.

58. Adam Y, Marcotty T, Cecchi G, Mahama Cl, Solano P, Bengaly Z, et al. Bovine trypanosomosis in the upper west region of Ghana: entomological, parasitological and serological cross-sectional surveys. Res Vet Sci. 2012;92: 462-8.

59. Aki A, Wogayehu Y, Chirkena K, Beyene G, Tekeba E, Teka G, et al. Epidemiology of cattle trypanosomosis and its vector density in Bullen district. Int J Vaccines Vaccin. 2016;2:00050.

60. Fisher AC, Schuster G, Cobb WJ, James AM, Cooper SM, de León AAP, et al. Molecular characterization of Trypanosoma (Megatrypanum) spp. infecting cattle (Bos taurus), white-tailed deer (Odocoileus virginianus), and elk (Cervus elaphus canadensis) in the United States. Vet Parasitol. 2013;197:29-42.

61. Njiokou F, Simo G, Nkinin SW, Laveissière C, Herder S. Infection rate of Trypanosoma brucei s.L., T. vivax, T. congolense "forest type," and T. simiae in small wild vertebrates in south Cameroon. Acta Trop. 2004:92:139-46.

\section{Submit your next manuscript to BioMed Central} and we will help you at every step:

- We accept pre-submission inquiries

- Our selector tool helps you to find the most relevant journal

- We provide round the clock customer support

- Convenient online submission

- Thorough peer review

- Inclusion in PubMed and all major indexing services

- Maximum visibility for your research

Submit your manuscript at www.biomedcentral.com/submit 